\title{
Towards an Integrated Framework for the Governance of a Territorialised Agroecological Transition
}

\author{
Pierre Triboulet, Jean-Pierre Del Corso, Michel Duru, Danielle Galliano, \\ Amélie Gonçalves, Catherine Milou, and Gaël Plumecocq
}

\begin{abstract}
This chapter aims to further our understanding of the governance mechanisms that might best support a territorialised agroecological transition (TAET). The challenge of governance is to coordinate the actions of a multitude of actors and to integrate different dimensions of agroecology. This challenge is portrayed as important in the sustainable agri-food systems literature, which seeks a convergence of governance approaches pertaining to either a Socio-Ecological Systems (SES) or a Socio-Technical Systems (STS)-oriented conception. Starting from a representation of the territory that combines these two approaches, we emphasize the importance of reflexive governance for collectively constructing a shared space of values and knowledge between actors. Case studies of eco-innovative food and energy projects in rural areas of Gers and Aveyron in France illustrate various governance mechanisms. Even if there are high expectations pertaining to the territory as a place for articulating public, market, and civil society actors around a shared vision of sustainable agri-food systems, there is still a long way to go before local governance of the transition becomes a reality, including from a long-term perspective.
\end{abstract}

P. Triboulet $(\bowtie) \cdot$ D. Galliano $\cdot$ A. Gonçalves $\cdot$ G. Plumecocq AGIR, Université de Toulouse, INRA, Castanet-Tolosan, France

LEREPS, Université de Toulouse, ENSFEA, Toulouse, France e-mail: Pierre.Triboulet@inra.fr; Danielle.Galliano@inra.fr; Amelie.Goncalves@inra.fr; Gael.Plumecocq@inra.fr

J.-P. D. Corso

LEREPS, Université de Toulouse, ENSFEA, Toulouse, France

e-mail: Jean-Pierre.Del-corso@educagri.fr

M. Duru

AGIR, Université de Toulouse, INRA, Castanet-Tolosan, France

e-mail: Michel.Duru@inra.fr

C. Milou

LEREPS, Université de Toulouse, ENSFEA, Toulouse, France

Coopérative Qualisol, Castelsarrasin, France

e-mail: c.milou@qualisol.fr 


\section{Introduction}

Governance can be defined as the set of mechanisms allowing a body of stakeholders to direct or steer a process in a desired direction. One of the pioneering aspects of governance is the emphasis that it places on the diversity of the actors involved or to be involved, in order to orient action. This diversity is presented as a safeguard against a single actor or type of actor seizing power, and as a way of integrating different viewpoints both on the process itself and on the way of steering it (hence, the introduction of a reflexive dimension in governance). In this sense, it contrasts with "governmentalities" mediated by representative democratic forms (Theys 2002). On the analytical level, the concept of governance requires that decisionmaking challenges be specified, which implies the identification of: (i) the boundaries of the system defining the social and political space within which these challenges are located; and (ii) the stakeholders in these challenges. On the operational level, governance relates to the mechanisms whereby these stakeholders drive the system to evolve toward the desired state.

This chapter aims at better understanding the governance mechanisms for supporting a territorialised agroecological transition (TAET). The challenge of governance is related to its capacity to coordinate the actions of a multitude of actors and to integrate different dimensions of agroecology, such as preserving biodiversity and agro-ecosystem resources, limiting pollution, developing product "quality", and so on. This challenge is portrayed as important in the sustainable agri-food systems literature, which seeks a convergence of governance approaches pertaining to either a Socio-Ecological Systems (SES)- or a Socio-Technical Systems (STS)-oriented conception (Ollivier et al. 2018). It is at the very core of the TATA-BOX project, which is based on a conceptual framework with three components - agriculture, natural resources, and the supply chain -, insofar as it stresses the importance of coordinating the dynamics of actors concerned by these three components of territories, in order to develop agroecological agriculture (Duru et al. 2015a). Within this framework, agriculture constitutes a meeting point between the productive, environmental, and agri-food dimensions of agroecology. However, the governance mechanisms of a TAET may vary, depending on the dimension prioritised or the way of qualifying different dimensions. The "agro-environmental" governance of interactions between agriculture and natural resources stems primarily from a socio-ecological system approach that emphasises medium- and long-term processes, as well as the role of government regulation. On the other hand, "agri-food" governance is more anchored in socio-technical system approaches, which put emphasis on the role of innovation as the driver of transitions.

The agroecological transition (AET) thus calls into question the political drive to integrate the productive and environmental dimensions of agriculture. The mechanisms for coupling these two dimensions constitute the nexus of the problem because they pertain to spatial and temporal scales, property rights, and modes of action that are not necessarily convergent (Hodge 2000). Hodge (2007) in particular raised the subject of this coupling by critically examining the production and value 
of an environmental good (landscape, biodiversity, carbon storage, flood prevention). An environmental good can be seen as a good coupled with an agricultural good; in other words, an increase in the production of the environmental good is expected, either as a result of the increased valuation of the agricultural good on agri-food or diversification markets, or because it belongs to a specific market related to ecosystem services, such as the one set up for carbon. Agricultural policies intended to modify agricultural practices are based on these underlying beliefs, with the goal of increasing the supply of ecosystem services treated as environmental goods (Hodge 2000). These policies may seek to penalise those that do not achieve the environmental standard, or to create incentives, via voluntary or systematic payments, to produce environmental goods. However, assessing the value of an environmental good is by no means simple. The ecological processes that underlie them have a significant degree of uncertainty; they are difficult to understand on the scale of a single actor, and even more on the scale of a group of actors; and they depend on different organisational levels. Knowledge requirements regarding environmental resources and associated management practices, and the mechanisms serving to orient practices in the desired direction have yet to be explored in more detail. It is therefore necessary to address the management of environmental resources within a flexible multi-actor framework offering the adaptive capacities necessary to manage complex systems (Folke et al. 2005). Hodge (2007) accordingly states that agri-environmental governance implies "a mix of regulation, markets, government incentives and collective decisions, set within a context of social institutions and norms".

Mount (2012) thus identifies the utility of a reflexive approach to governance, in which negotiation processes are a part of constructing the identity and legitimacy of the system implemented. Integrated agri-environmental governance in particular draws on this approach (Voß and Kemp 2006). Given that there does not exist " 'one' adequate problem framing, 'one' true prognosis of consequences, and 'one' best way to go that could be identified in an objective manner from a neutral, supervisory outlook" (Voß and Bornemann 2011), this approach aims at integrating the diversity of strategies, viewpoints, and expectations. From this perspective, change can be perceived as the result of diverse efforts to shape it. Reflexive governance implies that actors regularly question their representations and expectations, and can integrate new expectations into the process, which implies overcoming power relations between actors and the potential influence of dominant actors (Voß and Bornemann 2011).

This conceptualisation of agri-environmental governance shines light on the need to integrate different fields and actors in order to address the problem raised. It may put more emphasis on either the socio-environmental or the socio-technical dimension, depending on the preferred angle of attack. Governance also questions the methods of mobilising actors to act on the problem at hand. For example, collaborative governance puts emphasis on a new mode of public action based on a public institution mobilising a diversity of actors in order to enable collective decision-making (Ansell and Gash 2008). More broadly, it focuses on management and decision-making mechanisms engaging a diversity of actors in collectively 
constructing a common goal that could not otherwise be accomplished (Emerson et al. 2012). By contrast, the governance of socio-technical transitions and of value chains tends to focus on private actors, even though the place of public actors is not absent from the analysis framework.

The last dimension of governance to take into account is its instrumental nature. It has a capacity to act on the means of coordinating different points of view with respect to both the process itself and the way of steering it. Governance implies paying attention to the mechanisms that will enable the emergence of shared viewpoints in the context of multiple perspectives. However, it also clearly raises questions around power, leadership, and the distribution of roles (Huxham 2003). The mechanisms of collaboration between actors constitute a key dimension of governance, because throughout a transition they will determine the capabilities required for collective action (Emerson et al. 2012). Lastly, the spatial scale also appears as a key element in the governance literature (Baron 2003). Certain works position themselves on very large scales initially, such as literature on global value chains or climate governance, whereas others highlight more limited scales, in which case the actors participating in the governance are expected to have concrete experience regarding the transformations in play in the space in question. There is general agreement that this type of work relates to the idea of territory, which corresponds to local or regional levels of action (Glaser and Glaeser 2014). The TATA-BOX project gives priority to this level, which we thus seek to explicate more specifically. That being said, environmental, economic, and social processes do not stop at the boundaries of a given territory, and it is important to take into account the effects of higher levels, not viewing the territory as a closed space.

We first present governance approaches from the point of view of socio-ecological systems, followed by that of socio-technical systems, later moving on to present the overlap between these two approaches and to propose an integrated analysis framework. We then explore different pillars to prioritise in the case of integrated environmental agri-food governance, which we illustrate based on case studies.

\section{Different Approaches to Agri-environmental Governance}

\section{Socio-ecological Systems Governance}

The subject of the governance of the AET is emerging as society develops an awareness that agricultural activities directly or indirectly draw on a wide variety of natural resources (soil, water, biodiversity, etc.). The result is a significant effect on these resources, in three different ways at the very least (Nesme and Withers 2016):

- By reducing resource availability via their exhaustion, in particular for nonrenewable resources. Over-consumption can also disrupt the renewal of resources and reduce the capacities of future generations to meet their needs. 
- By modifying the state of resources by changing the structure or functionality of the ecosystem. Agricultural activity results in varying degrees of modification of flows, generating pollution, contamination, and degradation.

- By changing the allocation of resources. For example, this could be forests transformed into pastures.

Awareness of the effects of agriculture on natural resources is gradually undermining the productivist agriculture model. This model is based on a linear conception of relations between the economy and the natural environment (Pearce and Turner 1990). By contrast, the agroecological model that the public authorities aim to promote takes into account the dynamic and complex interrelations between agriculture or natural areas that are anthropised to varying extents. Swinton et al. (2007) thus demonstrate that agriculture benefits from and produces ecosystem services and disservices. Whereas on the one hand, to work properly, it depends on the quality of ecosystem services (Zhang et al. 2007), on the other hand, as a multifunctional activity (Wilson 2008), agriculture provides ecosystem services (carbon sequestration, landscape aesthetics, preservation of biodiversity, etc.). It can also cause ecological nuisances (water pollution, reduction in biodiversity, aggravation of health risks, etc.). This production of services and disservices will have either a positive or a negative effect on the well-being of other actors.

Agroecology, in its most accomplished form in the production and use of ecosystem services, therefore constitutes an eminently social and relational challenge (Le Roux et al. 2008). The various actors of a territory must coordinate to define the mechanisms of collective governance of ecosystem services. This is crucial, considering that the majority of these services are common goods ${ }^{1}$ for which the usage rights divided between actors are often poorly defined (Salles 2010).

Implementing governance of this type is however not self-evident. It requires a profound revision of ways of thinking and acting (cf. Fig. 1.) with, in particular: (i) a switch from a rationale of reducing the negative impacts of agriculture on the environment, to one of producing ecosystem services via biodiversity (Duru et al. 2015b), which implies shifting short-term strategies to long-term reasoning; (ii) and in parallel, a switch from a rationale of managing private goods (technical capital, chemical inputs, etc.) to one of managing common goods (water, biodiversity, etc.).

In this governance process, action is guided not only by individual interests, but also progressively by collective strategies. The market is therefore not the only form of coordinating relations between individuals, and more varied modes of organisation come to be included.

The challenge of the governance of agro-ecosystems in providing ecosystem services requires, in parallel and in addition to a change in the modes of organising collective action, a renewal of forms of public action. Therefore, the "Command and Control"-type public lever, based on a top-down logic, does not appear to be the most suitable one for supporting the social process of selecting the ecosystem services

\footnotetext{
${ }^{1}$ Rivalry and non-exclusion characterise a common good.
} 


\section{Public goods/Common resources}

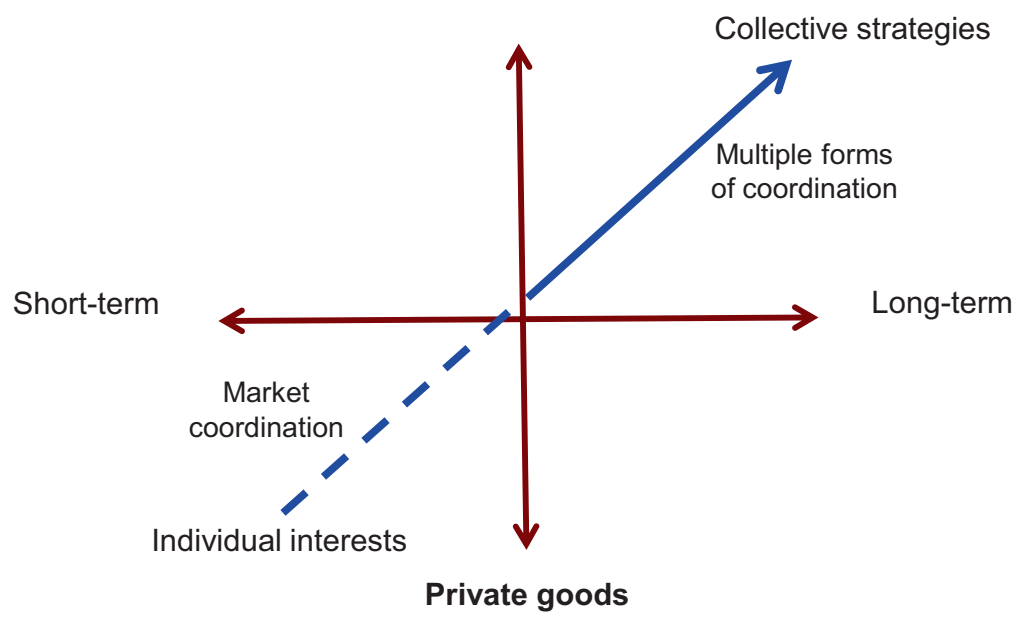

Fig. 1 The challenge of the governance of ecosystem services on the territorial scale

deemed to be worthy of attention on the territorial level. This process requires taking into account the features of the biophysical environments and socio-ecological relations specific to a given territory (Méndez et al. 2013). Moreover, it requires trade-offs between uses and values that are often multiple and competing. In this regard, Rodríguez et al. (2006) speak of "ecosystem services trade-offs" in the sense that the choice to preserve certain functionalities producing an ecosystem service will most often compete with that of other ecosystem services (Constans and Del Corso 2015).

Trade-offs between ecosystem services complicate the decision. Faced with this complexity, the role of public policies is above all to "orient" rather than to "steer" public action. Public bodies therefore make use of non-oriented regulation tools (Lascoumes and Simard 2011). These open up spaces facilitating coordination between territorial actors, on the basis of which they are able to choose the governance rules for producing ecosystem services. The choice of these rules is crucial, because it determines: (i) the scope of relevant actors (in particular the types of actors eligible to establish environmental goals); (ii) the mechanisms of the decision-making process; (iii) the way that ecosystem services are provided; and (iv) the way that costs and benefits are distributed between actors (Vatn et al. 2011; Vatn 2015). Consequently, these governance rules determine the level of engagement of actors in such a way as to encourage the preservation of environmental goods and services, and by doing so, give actors the chance to move beyond their personal interests. 


\section{The Governance of Socio-technical Systems}

The introduction of sociotechnical systems prioritises an approach to change driven by technical innovations and the organisational innovations supporting them. The company is the actor that is the focus of the system, and the goal is to better understand the determinants that will incentivise firms to eco-innovate, in other words, to produce innovations that prevent or reduce negative impacts on the environment (Horbach 2008). In addition to firms' internal features, these determinants relate to factors of a regulatory, technological, and market nature (Galliano and Nadel 2016). The combination of these factors, and namely the push/pull (constraint/incentive) effect of regulation, the pull effect of demand, and the push effect of technology are presented in the literature as having a positive influence on firms' engagement in eco-innovation (Horbach 2008). The literature has focused on mechanisms favouring the transition from a socio-technical system towards increased sustainability. The focal point becomes the socio-technical regime, which takes into account the fact that firms and technologies are integrated within a broader set of institutions, actors, and values contributing to organising a socio-technical system (Rip and Kemp 1998). The issue of the change to more sustainable practices thus raises the question not only of the nature of this change, and namely how radical it is, but also of the nature of the actors driving this change, which can be located in different positions at the centre or on the periphery of the dominant socio-technical regime (cf. chapter "Agroecological Transition from Farms to Territorialised Agri-Food Systems: Issues and Drivers").

Smith et al. (2005) posit that the governance of the sustainable transition of socio-technical systems will be based on two goals. First, it must aim at articulating the pressure around selection that drives a socio-technical regime to change. This selection pressure can stem from a broader economic or political landscape, such as a change in modes of consumption, or on the contrary, from small niches driving radical innovation. Depending on the case, transition governance could aim at protecting and strengthening innovation niches to prevent them from disappearing, or on the contrary, at incentivising their integration into the dominant regime. It is by articulating the different selection pressures that effective decisions can be taken as to the choices to prioritise. Second, the governance of a sustainable transition must undertake to strengthen the adaptive capacity of the socio-technical regime. In other words, not all regimes have the same predispositions to embed themselves within open innovation logics allowing them to integrate multiple viewpoints, decompartmentalise actors, and open themselves up to new ideas and knowledge. The networks and devices contributing to strengthening the adaptive capacities of a sociotechnical system are becoming crucial stakes for transition governance.

Whether it aims at driving changes within the dominant regime or via innovation niches, the governance of sustainable transition raises the question of the dynamics and modes of interaction between actors in socio-technical systems in a context of globalisation. Literature on global value chains and private standards has contrib- 
uted significantly to shedding light on the new modes of agri-food governance being implemented, and on their impact on a territorial scale.

Research on Global Value Chains (GVC) stems from the observation of a reconfiguration underway in the relations between actors in globalised supply chains. A GVC can be defined as "the full range of activities, including coordination, that are required to bring a specific product from its conception to its end use and beyond" (Gibbon and Ponte 2005: 77). This research has demonstrated the role of leading actors in the structuring and governance of these supply chains, and in particular in constructing normalisation and standardisation processes (Ponte and Gibbon 2005; Gereffi et al. 2005; Gibbon et al. 2008). It emphasises the complexity of this standardisation, which combines elements of public and private regulations, and which is integrating increasingly broader criteria (Bain et al. 2013). Gereffi and Lee (2009) thus distinguish three types of standards having a direct impact on the modes of coordination of actors: (i) health safety standards, which are mainly included in the decisions of supply chain actors via regulatory devices; (ii) product quality standards, which are mainly managed privately through quality coding devices (whether regulatory or not); and (iii) environmental and social standards, which require broader supervision of the production and transformation process to guarantee the quality of the standard in the eyes of consumers-citizens. The rapid increase in private standards - in particular environmental standards requires more coordination between supply chain actors, and highlights the growing role of certification and accreditation bodies in guaranteeing that the stated quality standard is indeed complied with by the different parties involved in the production, processing, and sale of the product (Hatanaka and Busch 2008; Konefal and Hatanaka 2010). The development of this private governance of environmental standards on the international scale raises the question of the place of local actors and of the territorial dimension.

Therefore, critical approaches to food governance seen through the lens of environmental standards highlight the fact that this governance was developed by large leading actors in supply chains (big corporations, distributors), and large environmental NGOs in the service of a narrow vision of the environment, associated with increasingly formalised procedures (Busch 2014). What followed was the rise to power of a standardised certification regime that could contribute to excluding local actors (Hatanaka 2014). Concretely, even if certification facilitates access to markets for local farmers and organisations by optimising management practices, the associated costs can be prohibitive and the benefits are not necessarily proven, as many publications in southern countries demonstrate (Konefal and Hatanaka 2010). Moreover, these certification practices can also contribute to imposing standards that fail to take local social and environmental problems into account (Bush et al. 2013) and that are detrimental to the perpetuation/creation of modes of production that do not comply with these norms. A case in point is fruit and vegetable supply chains, in which visual quality and size criteria are large constraints on practices (Bressoud and Parès 2010). 
Global supply chains are not, however, entirely devoid of local aspects, and they provide elements for reflecting on the implications of standardisation and localglobal articulation inherent to seeking value for food products produced by agroecology (Gereffi et al. 2005). Loconto (2015) shows how standards imposed remotely must be aligned with the interests of local actors to meet sustainability goals: "Local institutions and interests are stronger than 'rules' written into standards and the differences that we see in the practice of complying with standards is not so much about locally appropriating standards, but more about how governance at a distance is permitted because it is temporarily aligned with the interests, resources and obligations of the local actors" (Loconto 2015). It is this alignment between local and distant actors that could allow pathways to be anchored, to enable a sustainable transition in time and space. The adaptive capacities of the governance methods of global chains are at play here, in their ability to adapt "to local social and ecological contexts of production and consumption" (Boström et al. 2015). This also calls into question the dominant regime's capacity to include a diversity of local initiatives that may possibly challenge it. The local thus appears to be a focal point for reflexive governance aimed at better articulating the diversity of actors and dimensions (environmental, social, nutrition-health) contributing to sustainable food (Marsden 2013).

\section{An Integrated SES-STS Framework and Questions About Governance}

As illustrated in the previous two sections, SES and STS governance approaches are based on a conception of systems that mobilise various actors and resources (Duru et al. 2015a). SES governance emphasises the collective management of natural resources relating to multiple coordination methods. It de facto mobilises the actors and resources within a territory. STS governance places the emphasis on the coordination of economic actors (between them, with consumers, with civil society) in their capacity to integrate the environmental dimension as a driving factor in the transition of systems. These instances of coordination between actors vary in their restriction to a given territory and often raise the question of the articulation between the local and the global. ${ }^{2}$

The approximation of the two approaches is born of a dual tension related to the activity of agricultural production: on one hand, taking the productive dimension into consideration as an important component of natural resource management requiring the inclusion of the issue of agricultural production and its valorisation in the support of the ecological transition; and on the other hand, increasing awareness of the negative consequences of globalised food systems, from both the environmental and the health point of view (De Schutter 2017). Moving towards healthy and sustainable food systems has thus become a part of the research and public

\footnotetext{
${ }^{2}$ Note however that economic theory still has trouble integrating the territory into its analysis (Zimmermann 2008).
} 
policy agenda. This is why many voices have called for the expansion of the SES analysis framework to include a productive dimension. For example, McGinnis and Ostrom (2014) propose a change in the conceptual framework for socio-ecological systems that highlights the importance of "action situations". The goal is to examine how the social and ecological characteristics within a territory determine the actions of different actors and ultimately the achievement of different objectives and performances on the individual and collective scale. Marshall (2015) formalised the role of "transformation systems and products" for ecosystem goods by introducing a technical and technological system compartment (e.g. supply chains) at the interface between ecological and social systems, to address situations in which technologies are largely deterministic in the mode of exploiting natural resources (McGinnis and Ostrom 2014) and food systems(Vallejo-Rojas et al. 2016). Reciprocally, the literature on socio-technical systems has focused on the mechanisms to associate a wider diversity of actors and to integrate larger time scales in order to encourage sustainable transitions. Transition governance can therefore be conceived of within a two-dimensional space, the first dimension of which more specifically pertains to the SES component, and the other of which pertains to the STS component (cf. Fig. 2).

The governance of the agroecological transition (AET) must therefore aim at expanding the range of actors mobilised and at seeking better integration of components related to the market and public regulation (Hodge 2007). Research on agrifood systems demonstrates the existence of a diversity of agricultural systems that primarily use inputs that are biological and/or based on biodiversity and embedded within local versus globalised food systems. As the transition supports the idea of a change, it could therefore consist in endeavouring to identify the particularities of a mode of governance in favour of changes towards an ideal type of territorialised agri-food system. However, that would imply that the "ideal" agri-food system has been defined, and that the path to achieve it has been identified. Due to the complexity and overlap of the processes at play, transition paths are numerous and actors must be allowed to construct the paths that they wish to take themselves in order to promote the TAET (Duru et al. 2015a).

Adopting a reflexive perspective for the AET implies taking into account this diversity of ways of conceiving of agroecology and its embeddedness within agrifood systems, as well as the diversity of possible paths for this transition. The first key dimension of governance will therefore be to articulate a diversity of viewpoints or even oppositions between actors in order to allow actions to emerge in the context of the uncertainty and incompleteness of agroecology knowledge. The second dimension will be to encourage knowledge production and learning in such a way that the various stakeholders are drivers and pilots of changes, in particular farmers. The territory potentially becomes a key scale affirming the dynamics of collective actions to create added value and to strengthen the autonomy of actors (cf. chapter "An Integrated Approach to Livestock Farming Systems' Autonomy to Design and Manage Agroecological Transition at the Farm and Territorial Levels"). 


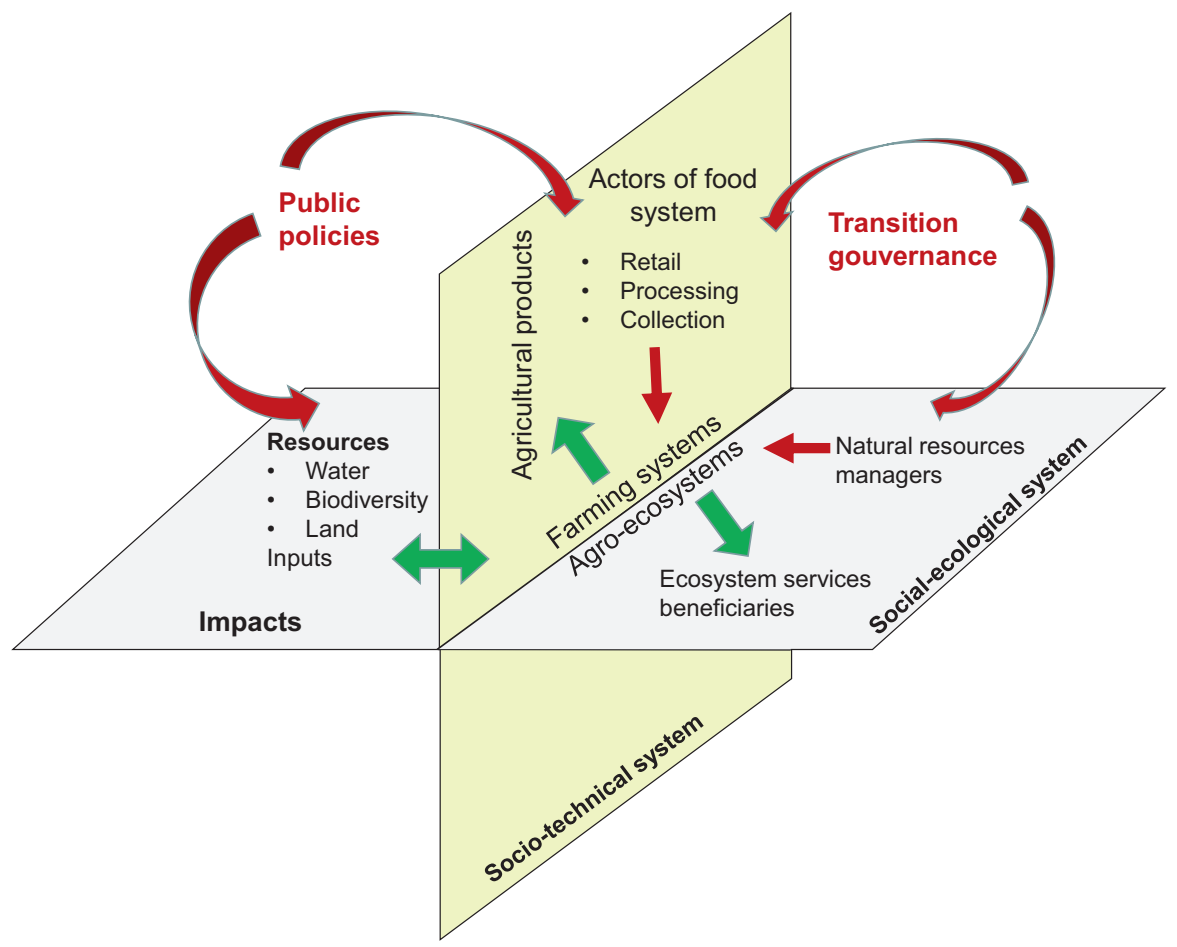

Fig. 2 Representation of a socio-ecological system (horizontal) and a socio-technical system (vertical) within a territory

Legend: farms and the agro-ecosystems that they manage are at the interface between the two systems. Green arrows indicate flows of products and services; burgundy arrows indicate decisions (rules, standards, subsidies). Transition governance mobilises actors in socio-ecological and sociotechnical systems as well as in public policy

\section{The Pillars to Prioritise for Integrated Environmental Agri-food Governance}

Stemming from the territory (SES) and the agri-food system (STS), this consists in examining which governance mechanisms a diversity of actors, including public actors, mobilise to promote agroecology, as well as the place of public policies and the local/territorial levels in agri-food systems.

\section{Reflexive Governance to Identify Value-Articulating Institutions}

The governance of the AET of a territory implies that the various concerns conveyed by different actors are taken into consideration. These concerns are justified by different systems of values or interests, which are potentially conflicting. Making the 
values or interests underpinning different transition strategies compatible with one another appears to be both a prerequisite and a result of governance. This governance can be articulated around "conventions" (in the sense of collective cognitive devices that support differing visions of agroecology (Plumecocq et al. 2018)), or on the contrary, can pertain to constructed rule sets. These rules define the mechanisms for implementing governance (for example, more or less restrictive/voluntarist), as well as the scope of stakeholders (more or less inclusive). Vatn (2005) calls these rule sets "value-articulating institutions", in other words, devices that aim at articulating and collectively establishing a hierarchy of different transition paths.

He relates the diversity of these devices to different property regimes (cf. diagram). For example, the consent to pay at the basis of the formation of market value and market negotiation devices constitutes a privileged institution in the governance of private goods. By contrast, frameworks for deliberation, such as citizen juries, deliberative or hybrid forums, multi-criteria valuations, or deliberative monetary valuations, have the purpose of informing the governance of common goods. Each of these frameworks is characterised by the pre-eminence granted to communications processes as a precedent to collective decision-making. In this sense, frameworks for deliberation reveal the construction of a system of values shared by governance stakeholders. ${ }^{3}$ The implementation of value-articulating institutions therefore ultimately relates to constructing collectively accepted governance solutions (Douai and Montalban 2012; Del Corso et al. 2017). Yet, upstream from deliberative processes, this search for legitimacy inherent to the governance process leads to two paradoxes: (i) what legitimate procedures support the decision on the form that value-articulating institutions must take on? and (ii) what procedures support the designation of the guarantor of the proper functioning of frameworks for deliberation? Let us consider these:

(i) In reality, if governance solutions draw their legitimacy from the deliberative nature of governance institutions, what is the source of legitimacy in the choice of the form of these institutions themselves? This choice is even more significant considering that the form of these institutions has an influence on mechanisms for expressing values, and to a certain extent on governance mechanisms. For example, expressing values in monetary terms seems to engage market coordination mechanisms.

(ii) It is important to point out that even if the ranking of the different roles of stakeholders in the governance of transitions may appear to be the result of deliberative processes, it can also reproduce relations of domination. The actor (potentially collective) that oversees the operation of value-articulating institutions themselves also possesses resources that it may use to its exclusive benefit. How is it possible to justify the legitimacy of the person fulfilling this role? While certain academic publications warn against the powers granted to experts

\footnotetext{
${ }^{3}$ However, beyond an agreement, it can also aim at establishing an entente, in the sense that each party understands the point of view of the other without necessarily being in agreement with them.
} 
in these devices (Van Tilbeurgh 2015), other publications highlight the role of scientists in steering deliberative devices (Fung 2006).

The involvement of scientists in the implementation of governance structures opens up a debate around the aspects that may be neglected by actors directly involved, such as the representation of the interests of absent third parties (future generations, other countries, the biosphere, etc.). By doing so, this involvement can create the necessary conditions for what Amartya Sen (2009) calls "open impartiality", because it contributes to taking into consideration "voices from far". The legitimacy of these researchers' role is however consubstantial with their professional ethics. Chapter "Evaluation of the Operationalisation of the TATA-BOX Process" provides hints on how such legitimacy is constructed. Ideally, stakeholders should be the judge of the well-founded nature of scientists' ethics and impartiality when taking into account the interests of absent third parties. If they are not well-founded, it is not possible to guarantee the legitimacy of the governance solutions resulting from a deliberative process steered by scientists.

Symmetrically, in certain situations characterised by the existence of scientific controversies surrounding essential aspects of the problem relevant to the implementation of governance, and which require rapid decision-making (thus precluding the production of stable knowledge), deliberative processes involving a large set of stakeholders are claimed to enrich scientific results. These situations pertain to what Godard (1993) calls controversial universes. When actors' perception of governance stakes is directly influenced by scientific knowledge (as in the case of the use of glyphosate or GMOs), it may be necessary to promote the hybridisation of expert and place-based knowledge. Deliberative forums can thus offer spaces for multi-actor collaboration allowing the renewal of registers of knowledge and action to deal with uncertainty (Callon et al. 2001). However, certain actors in the field may not have an interest in engaging in such collaboration. To preserve their individual interests, they may be tempted to sow doubt regarding the legitimacy of scientists in producing useful knowledge for governance.

\section{The Agri-food System as an Element Integrating Environmental, Social, and Economic Dimensions}

There is an abundant literature on local food systems as an agricultural production format that is more diversified and more respectful of the environment (Mount 2012). These systems can be seen as innovation niches where actors experiment with new modes of governance. However, Mount (2012) argues in favour of moving beyond a caricatural approach to the governance of local agri-food systems based on the premises of reconnection between production and consumption, direct links between farmers and consumers, and shared goals and values among these two types of actors. The actors that mobilise to reconnect agriculture, food, and the environment can be involved on different spatial scales and within different configurations, which generate different place-based reflexive governance configurations 
(Marsden 2013). Therefore, there is also the question of how different innovation niches coexist or are placed in tension with the dominant regime, and how the institutional landscape influences the various configurations observed.

One way of exploring TAET governance is by examining the range of actors ("private" actors, civil society, public actors, etc.) that will be stakeholders in the territorialised transition process. Vermeulen and Kok (2012) thus show that the different scenarios favouring sustainable products can be foreseen in terms of publicprivate regulation determining associated modes of governance. They examine these scenarios according to the role assigned to the public authorities. The first scenario pertains to classic public regulation based on restrictions and incentives. It is a form of central regulation that territorial actors can integrate into the governance, but over which they hold little sway. The second scenario of interactive regulation is based on the idea of collaboration between public and private actors aiming for private actors to be associated with or even drivers in the creation of measures promoting sustainable products, as is clearly seen in the development of private standards. The third scenario of self-regulation is based on initiatives by market and civil society actors. It is these actors that steer the processes, as public actors only play the role of supporting and facilitating these initiatives. Last of all, the authors identify a fourth scenario relating to the fact that public actors can be important economic actors as active consumers, for instance by recommending, through incentives or obligations, products for their cafeteria establishments.

Vermeulen and Kok (2012) examine how these four strategies are deployed in Holland around two supply chains: wood and coffee. By characterising the different phases of the development of environmental certifications for these two supply chains, they highlight the competition existing between various governance scenarios, and show that the place and role of public actors is essential, including to provide clear support for self-regulation. The development of organic agriculture is a good example of this coexistence of governance modes corresponding to different configurations of actors. The official labelling established by public policies is juxtaposed with collective private labelling resulting from coordination between actors that is at times territorialised. While public policies as well as markets and consumers support the dynamics of organic agriculture today, many questions remain unanswered as to related modes of governance promoting agroecological practices. In particular, this calls into question the relationship between public policies targeting production and the environment (via the CAP), and environmental certification that is increasingly tied to private market actors (Forney 2016). Many expectations concern the territory as a place for articulating public, market, and civil society actors around a shared vision of sustainable agri-food systems. Yet the local governance of these systems remains a major challenge, including over the long term. For more than 30 years, the Biovalley project in the Drôme region has been mobilising local institutions and a set of producers to develop an "organic" territory. Its success is related primarily to its capacity to mobilise a significant number of European funding mechanisms over the long term (Lamine 2015). However, many conflicts exist between project promoters and local institutions, as well as between actors included within the project and those excluded. Lamine (2015) thus notes 
that the inclusion of citizens and NGOs in the Biovalley project is likely to be a significant challenge in the near future in building a shared vision of the territory.

A few examples from the rural territories of Aveyron and neighbouring départements concretely demonstrate the various dimensions of governance considered in this chapter.

The analysis of the trajectory of eco-innovative agri-food projects and of methanation allows us to characterise different governance mechanisms use in steering these projects (Box 1). Stemming from local initiatives involving farmers, these

\section{Box 1: The Central Role of Farmers in the Governance of Eco- innovative Food and Energy Projects}

This study is on five eco-innovative projects in rural areas of Aveyron and Gers (Nuts 3 level) (Galliano et al. 2017). The environmental dimension is central in two of these projects, as they are collective methanation projects in Aveyron. The other three are agri-food projects with an environmental dimension (a local bread supply chain in Aveyron with agroecological practices, a sheep cheese supply chain in Aveyron partially from organic agriculture, and a large-scale organic crop supply chain in Gers).

While all of these projects involve an environmental component, they neither position themselves as nor necessarily lay claim to being AET actions. Concretely, it is primarily their economic and social impact on the territory that stakeholders highlight. These five initiatives convey the will of actors to engage in a collective process aimed at regaining leeway with respect to a global context that endangers the continuance of their activities or drives them towards strategies that they do not want to adopt. The same desire to create added value for farmers in the territory is present throughout these projects, in the context of the process steered by these farmers.

The central role of farmers is the common denominator of the governance of these initiatives. Yet the governance of the supply chains differs from that of methanation in terms of the scope of actors concerned, decision-making mechanisms, market integration, public-private relations, and time frames.

The three supply chains are characterised by self-regulating governance (Vermeulen and Kok 2012). They are projects stemming from the desire of economic actors within the same territory to establish a new offering combining agricultural production and transformation, and based on local know-how and the image of the territory. Therefore, the farmers and cooperatives involved are increasingly integrating the market into their strategy. This can either take place through the development of cooperative-run processing and distribution activities for the national or international market (cheese and grain supply chains), or through the creation of an inter-professional association grouping together all actors throughout the entire (bread) supply chain for local demand. 


\section{Box 1 (continued)}

All the stakeholders collectively define the goals of the three supply chains, the ways of achieving them, and the rules governing coordination. This takes place either through representatives or through the direct involvement of each individual (cheese supply chain). The rules of the collective's operation are quickly formalised (for instance through technical specifications) in order to guarantee the engagement of each person. This rapid formalisation reflects the time frame of these projects, which are implemented over a few months in order to rapidly provide outlets to the farmers in question. The speed of this implementation can also be explained by the convergence of the macroeconomic context of the sectors in question with national and European public policies creating incentives or offering assistance for implementing such projects. Public actors in the territory (administrations or local governments) subsequently remain in the background, capable of facilitating initiatives on a one-time basis or getting involved by providing means, but not intervening in defining the project and its orientations. Given that the valorisation of the territory's resources (both tangible and intangible) is at the heart of these projects, significant support is also drawn from local professional networks (Chambers of Agriculture, professional training organisations, etc.) that do not play a direct role in governance but generally prove to be important in helping to define possible strategic options.

As for the two methanation projects, they are characterised by interactive governance that closely intertwines the involvement of public and private actors. These projects were initiated following European policies for promoting renewable energy transposed to the national level. Local elected officials were the spearheads for these projects alongside farmers, who also became leaders in the initiative. These initiatives were therefore initially structured via a very limited hard core of public and private actors that subsequently expanded to a large workgroup with many farmers. While the jurisdictions of local governments and municipal groups did not allow them to develop ad hoc policies to benefit methanation, they made a significant contribution by providing resources (financing, advising, logistics) and by contributing to defining the strategy via the participation of elected officials in workgroups. Throughout the lifespan of projects, national and European policies remained deterministic factors in their evolution, over which local actors sought to have an influence by mobilising regional elected officials or state agents. This regulatory context over which actors had little sway contributes to explaining the time frame of projects. These are initiatives that required several years to truly structure themselves. The first stage, consisting of defining major orientations, was characterised by coordination between actors that was largely informal. By contrast, the second phase, that of project implementation, was supported by a much higher degree of formalisation (establishment of firms, 
Box 1 (continued)

signing of contracts), in order to guarantee the perpetual engagement of each person (including farmers).

Even though these methanation projects do contain a territorial anchoring component, this appears to be less significant than for the three supply chain projects, due to the lower degree of mobilisation of local actors and resources. This is mainly explained by the fact that these projects, despite drawing support from local agricultural resources, used a technology that was new for the territories in question, and mainly intended to produce energy consumed outside of these territories. This also explains how external actors (public banking, methaniser manufacturers, etc.) gradually came to form a part of the project, informally at first and then by becoming shareholders and thus explicitly participating in governance. The farmers nevertheless remained heavily involved in governance. As key members of workgroups, they later became majority shareholders in the firms driving the project. As a whole the farmers concerned were consulted in important decisions/orientations that they nonetheless did not necessarily make, as their representatives were responsible for the more everyday aspect of governance.

projects are rooted in formal organisations that constitute the medium for knowledge exchange and value sharing among actors. Agri-food projects are the result of economic actors in a single territory wishing to construct a new offering combining agricultural production and transformation, as well as developing the image of a territory pushing for sustainable agriculture. The governance is self-regulating (Vermeulen and Kok 2012) and aims at associating the different links in the supply chain in order to agree on product quality goals and on the means and knowledge to develop and share, in order to achieve them. This governance is often based on the key role of a few individuals with the capacity to enrol and mobilise a diversity of actors and knowledge. Even though consumers are not stakeholders in these projects, a key element of their success is tied to the success of products on local or more distant markets, indicative of the capacity of alignment of the local interests of agricultural actors with demands that are often remote. Methanation projects are based on more interactive governance because they mobilise local public actors to a greater extent. However, even though there exist clearly-displayed public support policies and these projects consist in developing resources locally, they have trouble establishing themselves due to complex and constantly changing regulations (which generate uncertainty), and to the greater diversity of actors involved, which makes it difficult to establish a shared goal. The gap between environmental standards reflecting national methanation legislation and local interests, values, and resources clearly appears here to be an obstacle to these environmental projects.

The development of a dried legumes supply chain by a cooperative illustrates private governance aiming at establishing a system of shared values (Box 2). While 


\section{Box 2: Governance as Constructing a System of Shared Values: The Example of a Dried Legumes Supply Chain Implemented by an Agricultural Cooperative}

The concrete case of an agricultural cooperative's development of a legume supply chain, which underlies an initiative embedded within the tenets of the AET, can offer a specific example of the challenges of governance founded on the creation of a system of shared values. The success of such an initiative essentially relies on multiple categories of actors, operators, farmers, and consumers.

\section{An agroecological transition driven by a cooperative facing a dual challenge}

Established in the Tarn et Garonne and Gers départements (Nuts 3 level), the Qualisol agricultural cooperative wagered on the development of a dried legume supply chain. In light of the agronomic, food, and environmental benefits expected fromv the development of these legume crops, this project can be understood as a territorialised AET initiative. It nevertheless collided with multiple obstacles and uncertainty factors.

For the cooperative, the challenge proved to be twofold: first, it had to successfully take up a satisfactory position in a market that was still unstable and in which other competing operators were present; and second, it had to be capable of getting its farmer members to grow legume crops over the long term in order to lay the foundations of the supply chain.

With regard to the first challenge, the cooperative had to be successful in setting itself apart, to capture the attention of potential customers and to offer products capable of convincing consumers at the end of the chain. However, despite the growing body of knowledge on the nutritional advantages of legumes, ${ }^{4}$ this type of food remains relatively unknown. Consumers also mention obstacles to consumption with regard to digestibility, the practicality of using them, and so on. Promoting the consumption of legumes was thus tied to improving the information on these products and modernising their image and the ways of using them.

Concerning the second challenge, garbanzo bean or lentil crops can offer relative financial security through the signing of contracts. This is however undermined by the uncertainty of the success of these crops, which require the acquisition of new technical know-how. This security is also limited by farmers' lack of understanding of their benefits on a rotational multi-year scale.

(continued)

\footnotetext{
${ }^{4}$ This information was updated as a part of the nutritional recommendations of the Haut conseil de la santé publique (the high council for public health) under the Programme National Nutrition Santé 2017-2021 (national health and nutrition plan 2017-2021).
} 


\section{Box 2 (continued)}

Lastly, it can suffer due to an annual profitability considered to be unsatisfactory when compared with other better-controlled crops. Effectively, the agronomic benefits attributed to legumes, despite generally being known to farmers, are barely considered little in assessments of the direct value of these crops.

\section{Collective learning to reduce the uncertainty of producers and consumers}

The cooperative used multiple levers to overcome this dual challenge.

First of all, it supported itself by establishing its own brands in both the organic supply chain and the conventional supply chain, in order to hold extended control over the downstream part of the chain. The organic supply chain, developed first, and which had a higher security margin (better price stability, rotational approach more customary among farmers in the organic system, better informing of consumers, and popularity of the organic label), allowed the cooperative to acquire know-how on these products while limiting risk-taking. It was thus able to make use of this learning to later develop its supply chain in the conventional market. For the latter, the cooperative also wished to establish a positive image setting it apart in the eyes of customers and consumers through the "Haute valeur environnementale" (HVE, high environmental value) certification approved by a set of technical specifications, compliance with which is supervised by an independent certification body. Therefore, within both supply chains, the cooperative highlighted the origin of products, which by being associated with HVE or organic specifications, offered clients and consumers security in terms of production transparency.

The cooperative also aims at diversifying dried legumes crops (multiple species of beans, chickpeas, lentils) in such a way as not only to strengthen its appeal among clients through a broad product range, but also to play on consumers' curiosity and interest. The cooperative moreover purchased shares in a processing company to offer dried legumes in a form ready to use in salads, cooked dishes, and dough/pastry.

This process seeking to secure the desired production on the market through differentiation is reflected in its economic valuation, which is capable of making investments profitable and convincing farmers to produce these crops. It is also backed by a second lever directed at the latter: that of collective action. This is manifest in the Groupes d'Intérêts Economiques et Environnementaux (GIEE, economic and environmental interest groups) framework. This collective framework offers a form of security by throwing questions, failures encountered, and solutions tested into a communal pot in order to jointly identify factors in success. In its structure, the GIEE also encompasses other categories of partners (commune communities, associations, federations, economic organisations, etc.). Because of this, it represents 


\section{Box 2 (continued)}

an excellent method for exchange between multiple categories of actors that are stakeholders in the success of a territorialised supply chain.

Therefore, through its multi-actor and inclusive approach, the cooperative was successful in establishing an original mode of governance capable of articulating, between these multiple actors, the multiplicity of environmental, agronomic, and food values transmitted by the actors present. The concept of quality is at the heart of this articulation. Concretely, it is around a shared definition of quality that the convergence of producer and consumer preferences is able to take place. In fact, an agreement on quality as a value-articulating institution represents a crucial governance concern in and of itself. This agreement is such as to trigger a broadening of modes of thought and types of action. Because of this, it can appear to be a factor in reducing uncertainty for different categories of actors, thus securing their actions as well as orienting these actions in a direction that appears desirable to them.

the desire to be embedded within a TAET initiative is the driver of the cooperative's engagement, it is faced with the dual challenge of finding booming markets to sell these dried legumes and incentivising farmers to grow these crops, on which they lack knowledge and resources. For the first challenge, the cooperative developed various strategies for creating the value of these products around its own brand, and by constructing a specialised network allowing it to establish credible and lucrative quality markings. For the second challenge, it drew on the support of collective action by creating a multi-partner GIEE (Groupe d'Intérêt Economique et Environnemental (economic and environmental interest group) allowing it to create the conditions for exchanging knowledge on the practices to implement. In both cases, the quality agreement appears to be the value-articulating institution allowing the different stakeholders' preferences to emerge.

The last example stems from research on territorial protein autonomy based on interaction between grain and livestock farmers in the Aveyron Valley (Box 3). Several multi-partner participatory workshops served to establish scenarios for the reduction of irrigated maize crops, to be replaced by alfalfa for dairy farmers (Moraine et al. 2016). While actors, and in particular farmers, agreed on the benefits of such interaction, it was the concrete implementation of the governance necessary to set them up that constituted an obstacle in this case. No actor was identified as having the capabilities necessary to define the value-articulating institution supporting these interactions. Integrating a public actor such as the Agence de l'eau (water agency) could therefore constitute a solution for interactive governance between a public actor, an agricultural cooperative, and farmers.

These examples testify to the social challenges associated with the governance of the rural the TAET. Behind these initiatives are a diversity of actors, including farmers, seeking increased economic value for the local resources of their territory, 


\section{Box 3: Towards Governance of Exchanges Between Grain and Livestock Farmers: The Example of Multi-cropping-livestock Farming in Aveyron (Moraine et al. 2016)}

The specialisation of regions and farms has compounded the environmental impacts of agriculture due to the mass use of inputs and an increase in the vulnerability of farms in a context of high inter-year climate variability. To way to meet these challenges is to diversify farm productions, which is associated with exchanges between specialised farms within small territories. This orientation requires not only a revision of the mode of managing resources within a territory to reduce their consumption and/or impacts, but also a deeper or shallower reorganisation of supply chains in order to adapt to this diversification.

By representing the agriculture in a given territory as a socio-ecological system, it is possible to identify environmental challenges, the actors concerned by the resource (consumption and impacts), and levers for action. Representing the dominant supply chains in a territory as a socio-technical system allows us to evaluate the degree of reorganisation necessary to achieve environmental goals as well as feasibility in economic terms and with regard to the organisation of work. In other words, these two frameworks of analysis cross-compare governance in socio-ecological and in socio-technical systems, to identify the shared aspects or incompatibilities between them.

This cross-comparison was applied in the Aveyron Valley, where the upstream is characterised by the concentration of surface areas as temporary and permanent grasslands, while the downstream is dominated by large-scale cropping areas for maize, grains, and sunflower. This juxtaposition within this basin of a zone specialised in livestock farming and one dominated by largescale cropping is representative of many grassland/hillside situations in France. Each zone has a certain amount of diversity of production systems, but these systems tend to specialise.

A participatory diagnosis of concerns related to cropping-livestock farming integration in the Aveyron basin was carried out. This diagnosis was based on an initial workshop bringing together a wide variety of participants (farmers, advisers at chambers of agriculture, cooperative technicians, the Agence de l'Eau (water agency), and representatives of an environmental non-profit association). Iterative work at the workshop allowed participants to establish multiple scenarios, the common aspects of which were: (i) reducing the surface area of irrigated maize by replacing it with alfalfa sold to livestock farmers, thus allowing for water savings and the maintenance of the economic performance of large-scale cropping farms; (ii) strengthening the place of alfalfa on dairy farms, and thus increasing the protein autonomy of the territory. 
Box 3 (continued)

One challenge is designing the contractual mechanisms of interaction between crop and livestock farmers (prices of materials exchanged, price and volume guarantees, logistics, financing, etc.) and checking with the water agency that these changes in technical systems are consistent with the resource governance plan. This contractualisation could therefore be tripartite (farmers, collection agency, and water agency). Organisational innovations should consequently be devised to deploy and perpetuate such arrangements, taking into account that the farmers present do not have experience or benchmarks for this. It is therefore recommended to implement reflexive governance.

This example is relatively simple insofar as the technical change is limited to production and logistics, but does not result in changes in transformation, distribution, and food choices.

alongside environmental benefits. While the market dimension is strongly present in the projects used as an example in this chapter, particularly to develop the value of the agroecological production approach in the eyes of consumers, the latter are not closely associated with their governance. And although this illustrates a difference with respect to urban agri-food systems, in which consumers are often drivers (Sonnino 2017), the desire to open up to a diversity of supply chain and territorial actors, including regional governments, is testimony to changes in modes of governance of rural agri-food systems, with a shift from agri-industrial systems governance to territorialised food systems governance (Lamine et al. 2012).

\section{Conclusion}

This chapter is based on the argument that there is not only one archetype of governance for the TAET. On the territorial scale, a variety of initiatives exist, contributing to the agroecology of practices and embedded within various agri-food systems. This relates to a representation of the territory that combines a horizontal dimension pertaining to socio-ecological systems, and a vertical dimension pertaining to socio-technical systems. The challenge is therefore to identify the different governance mechanisms that will favour the AET process. The literature agrees on the importance of reflexive governance in collectively constructing a shared space of values and knowledge that set in motion increasingly agroecological practices. It also highlights the fact that environmental governance requires the association of a diversity of private and public actors, as well as the integration of a combination of 
regulations, markets, and collective action. In this context, the territory appears to be a place of tension, articulating the construction and reappropriation dynamics of local actors and the local redeployment dynamics of more global actors. One marker of these tensions is the entry of sustainable agri-food systems, from local niche systems up to globalised systems.

In the second section we first focused on the ways of making actors' preferences converge around a shared goal. In particular, we highlighted the importance of value-articulating institutions in establishing collectively accepted governance solutions. The undertaking to identify and legitimise value-articulating institutions is at the core of governance stakes, and in particular raises the question of the place of scientific knowledge. After that, we went over Vermeulen and Kok (2012) typology of modes of governance. This typology allows us to specify the role of public actors with regard to the governance problem posed, from a distant role by regulation (central governance), to participation in governance (interactive governance), the support of economic actors and civil society (self-regulated governance), and even an active role as a market actor (for instance through school cafeterias). A few case studies of eco-innovative food and energy projects in the rural territories of Aveyron and neighbouring départements allowed us to illustrate the mechanisms of interactive and self-regulated governance. For agri-food projects, the quality of products and associated standardisation processes constitute the value-articulating institution that orients the practices of all actors throughout the value chain. For projects for exchanges between grain and livestock farmers or methanation projects, difficulties were experience in setting up coordination around a value-articulating institution. Lastly, the success of projects appears to be related to the capacity of leading actors to integrate a diversity of actions and to mobilise stakeholders as a whole towards a common path.

Our conclusions are in line with those highlighted in the literature. Even if there are high expectations pertaining to the territory as a place for articulating public, market, and civil society actors around a shared vision of sustainable agri-food systems, there is still a long way to go before local governance of the transition becomes a reality, including from a long-term perspective (Lamine 2015). This relates to local actors' capacity for defining a goal shared by the different stakeholders of the territory and for providing themselves with the means to achieve this goal. Moreover, it also relates to their capacity for integrating expectations that are external to the territory in question, whether nearby towns or embedded within globalised agrifood systems. Regarding the latter point, Boström et al. (2015) notes that the major challenge of governance in moving towards increased sustainability: "A broader social science view on supply chains is necessary if we are to understand how unsustainable practices (continue to) prevail and how more sustainable ones could be facilitated. Yet we are only beginning to understand the enormous governance challenges facing state and non-state actors, networks, organizations and individuals to - in a constructive and responsible manner - handle the economic, social and ecological complexities associated with global supply chains". 


\section{References}

Ansell C, Gash A (2008) Collaborative governance in theory and practice. J Public Adm Res Theory 18:543-571. https://doi.org/10.1093/jopart/mum032

Bain C, Ransom E, Higgins V (2013) Private agri-food standards: contestation, hybridity and the politics of standards. Int J Agric Food 20:1-10

Baron C (2003) La gouvernance: débats autour d'un concept polysémique. Droit et société 2:329-349

Boström M, Jönsson AM, Lockie S et al (2015) Sustainable and responsible supply chain governance: challenges and opportunities. J Clean Prod 107:1-7. https://doi.org/10.1016/j. jclepro.2014.11.050

Bressoud F, Parès L (2010) Quelles références pour une production de légumes de territoire ? In: Muchnik J, de Sainte Marie C (eds) Le temps des SYAL, Techniques. Cairn.info, Paris, pp 211-228

Busch L (2014) Governance in the age of global markets: challenges, limits, and consequences. Agric Hum Values 31:513-523. https://doi.org/10.1007/s10460-014-9510-x

Bush SR, Belton B, Hall D et al (2013) Global food supply. Certify sustainable aquaculture? Science 341:1067-1068. https://doi.org/10.1126/science.1237314

Callon M, Lascoumes P, Barthe Y (2001) Agir dans un monde incertain. Essai sur la démocratie technique. Seuil, Paris

Constans M, Del Corso JP (2015) L'évolution des paysages viticoles de Banyuls: les politiques publiques face à des enjeux environnementaux paradoxaux. In: Béringuier P, Blot F, Desailly B, Saqalli M (eds) Environment. France, Paris, pp 457-477

De Schutter O (2017) The political economy of food systems reform. Eur Rev Agric Econ 44:705731. https://doi.org/10.1093/erae/jbx009

Del Corso J-P, Nguyen TDPG, Kephaliacos C (2017) Acceptance of a payment for ecosystem services scheme: the decisive influence of collective action. Environ Values 26:177-202. https:// doi.org/10.3197/096327117X14847335385517

Douai A, Montalban M (2012) Institutions and the environment: the case for a political socioeconomy of environmental conflicts. Camb J Econ 36:1199-1220. https://doi.org/10.1093/cje/ bes046

Duru M, Therond O, Fares M (2015a) Designing agroecological transitions: a review. Agron Sustain Dev 35:1237-1257. https://doi.org/10.1007/s13593-015-0318-x

Duru M, Therond O, Martin G et al (2015b) How to implement biodiversity-based agriculture to enhance ecosystem services: a review. Agron Sustain Dev 35:1259-1281. https://doi. org/10.1007/s13593-015-0306-1

Emerson K, Nabatchi T, Balogh S (2012) An integrative framework for collaborative governance. J Public Adm Res Theory 22:1-29. https://doi.org/10.1093/jopart/mur011

Folke C, Hahn T, Olsson P, Norberg J (2005) Adaptive governance of social-ecological systems. Annu Rev Environ Resour 30:441-473. https://doi.org/10.1146/annurev. energy.30.050504.144511

Forney J (2016) Blind spots in agri-environmental governance: some reflections and suggestions from Switzerland. Rev Agric Food Environn Stud 97:1-13

Fung A (2006) Varieties of participation in complex governance. Publ Adm Rev 66:66-75. https:// doi.org/10.1111/j.1540-6210.2006.00667.x

Galliano D, Nadel S (2016) Les processus sectoriels de l'innovation environnementale: les spécificités des firmes agroalimentaires françaises. Économie Rural 356:47-67. https://doi. org/10.4000/economierurale.5055 
Galliano D, Gonçalves A, Triboulet P (2017) Eco-innovations in rural territories: organizational dynamics and resource mobilization in low density areas. J Innov Econ Manag 24:35-62. https://doi.org/10.3917/jie.pr1.0014

Gereffi G, Lee J (2009) A global value chain approach to food safety and quality standards. Working paper. Duke University, Durham

Gereffi G, Humphrey J, Sturgeon T (2005) The governance of global value chains. Rev Int Polit Econ 12:78-104. https://doi.org/10.1080/09692290500049805

Gibbon P, Ponte S (2005) Trading down: Africa, value chains, and the global economy. Temple University Press, Philadelphia

Gibbon P, Bair J, Ponte S (2008) Governing global value chains: an introduction. Econ Soc 37:315-338. https://doi.org/10.1080/03085140802172656

Glaser M, Glaeser B (2014) Towards a framework for cross-scale and multi-level analysis of coastal and marine social-ecological systems dynamics. Reg Environ Chang 14:2039-2052. https://doi.org/10.1007/s10113-014-0637-5

Godard O (1993) Stratégies industrielles et conventions d'environnement: de l'univers stabilisé aux univers controversés. INSEE Méthodes 39-40:145-174

Hatanaka M (2014) Standardized food governance? Reflections on the potential and limitations of chemical-free shrimp. Food Policy 45:138-145. https://doi.org/10.1016/j. foodpol.2013.04.013

Hatanaka M, Busch L (2008) Third-party certification in the global agrifood system: an objective or socially mediated governance mechanism? Sociol Ruralis 48:73-91. https://doi. org/10.1111/j.1467-9523.2008.00453.x

Hodge I (2000) Agri-environmental relationships and the choice of policy mechanism. World Econ 23:257-273. https://doi.org/10.1111/1467-9701.00271

Hodge I (2007) The governance of rural land in a liberalised world. J Agric Econ 58:409-432. https://doi.org/10.1111/j.1477-9552.2007.00124.x

Horbach J (2008) Determinants of environmental innovation-new evidence from German panel data sources. Res Policy 37:163-173. https://doi.org/10.1016/j.respol.2007.08.006

Huxham C (2003) Theorizing collaboration practice. Publ Manag Rev 5:401-423. https://doi. org/10.1080/1471903032000146964

Konefal J, Hatanaka M (2010) The Michigan State University School of Agrifood governance and technoscience: democracy, justice, and sustainablity in an age of scientism, marketism, and statism. J Rural Soc Sci 25:1-17

Lamine C (2015) Sustainability and resilience in agrifood systems: reconnecting agriculture, food and the environment. Sociol Ruralis 55:41-61. https://doi.org/10.1111/soru.12061

Lamine C, Renting H, Rossi A et al (2012) Agri-food systems and territorial development: innovations, new dynamics and changing governance mechanisms. In: Darnhofer I, Gibbon D, Dedieu B (eds) Farming systems research into the 21st century: the new dynamic. Springer, Dordrecht, pp 229-256

Lascoumes P, Simard L (2011) L'action publique au prisme de ses instruments. Rev française Sci Polit 61:5-21. https://doi.org/10.3917/rfsp.611.0005

Le Roux X, Barbault R, Baudry J et al (2008) Agriculture et biodiversité, ESCo. INRA France, Paris

Loconto A (2015) Assembling governance: the role of standards in the Tanzanian tea industry. J Clean Prod 107:64-73. https://doi.org/10.1016/j.jclepro.2014.05.090

Marsden T (2013) From post-productionism to reflexive governance: contested transitions in securing more sustainable food futures. J Rural Stud 29:123-134. https://doi.org/10.1016/j. jrurstud.2011.10.001 
Marshall GR (2015) A social-ecological systems framework for food systems research: accommodating transformation systems and their products. Int J Commons 9:1-28. https://doi. org/10.18352/ijc.587

McGinnis M, Ostrom E (2014) Social-ecological system framework: initial changes and continuing challenges. Ecol Soc 19:30. https://doi.org/10.5751/ES-06387-190230

Méndez VE, Bacon CM, Cohen R (2013) Agroecology as a transdisciplinary, participatory, and action-oriented approach. Agroecol Sustain Food Syst 37:3-18. https://doi.org/10.1080/1044 0046.2012.736926

Moraine M, Grimaldi J, Murgue C et al (2016) Co-design and assessment of cropping systems for developing crop-livestock integration at the territory level. Agric Syst 147:87-97. https://doi. org/10.1016/j.agsy.2016.06.002

Mount P (2012) Growing local food: scale and local food systems governance. Agric Hum Values 29:107-121. https://doi.org/10.1007/s10460-011-9331-0

Nesme T, Withers PJA (2016) Sustainable strategies towards a phosphorus circular economy. Nutr Cycl Agroecosyst 104:259-264. https://doi.org/10.1007/s10705-016-9774-1

Ollivier G, Magda D, Mazé A et al (2018) Agroecological transitions: what can sustainability transition frameworks teach us? An ontological and empirical analysis. Ecol Soc 23:18. https:// doi.org/10.5751/ES-09952-230205

Pearce DW, Turner RK (1990) Economics of natural resources and the environment. Harvester Wheatsheaf, London

Plumecocq G, Debril T, Duru M et al (2018) Caractérisation socio-économique des formes d'agriculture durable. Accepté Économie Rural:99-120. https://doi.org/10.4000/ economierurale. 5430

Ponte S, Gibbon P (2005) Quality standards, conventions and the governance of global value chains. Econ Soc 34:1-31. https://doi.org/10.1080/0308514042000329315

Rip A, Kemp R (1998) Technological change. In: Rayner S, Malone E (eds) Human choices and climate change, vol 2. Battelle Press, Columbus, pp 327-399

Rodríguez JP, Beard TD, Bennett EM et al (2006) Trade-offs across space, time, and ecosystem services. Ecol Soc. https://doi.org/10.2307/26267786

Salles J-M (2010) Évaluer la biodiversité et les services écosystémiques: pourquoi, comment et avec quels résultats? Natures Sci Sociétés 18:414-423. https://doi.org/10.1051/nss/2011005

Sen A (2009) The idea of justice. Belknap Press of Harvard University Press, Cambridge, MA

Smith A, Stirling A, Berkhout F (2005) The governance of sustainable socio-technical transitions. Res Policy 34:1491-1510. https://doi.org/10.1016/j.respol.2005.07.005

Sonnino R (2017) The cultural dynamics of urban food governance. City Cult Soc. https://doi. org/10.1016/J.CCS.2017.11.001 (in press)

Swinton SM, Lupi F, Robertson GP, Hamilton SK (2007) Ecosystem services and agriculture: cultivating agricultural ecosystems for diverse benefits. Ecol Econ 64:245-252. https://doi. org/10.1016/j.ecolecon.2007.09.020

Theys J (2002) La Gouvernance, entre innovation et impuissance. Développement durable Territ 2:28. https://doi.org/10.4000/developpementdurable.1523

Vallejo-Rojas V, Ravera F, Rivera-Ferre MG (2016) Developing an integrated framework to assess agri-food systems and its application in the Ecuadorian Andes. Reg Environ Chang 16:21712185. https://doi.org/10.1007/s10113-015-0887-x

Van Tilbeurgh V (2015) La négociation dans les dispositifs environnementaux: De la construction d'asymétries à l'imposition de préférences. ESO Travaux \& Documents 38

Vatn A (2005) Institutions and the environment. Edward Elgar Publishing, Cheltenham

Vatn A (2015) Markets in environmental governance. From theory to practice. Ecol Econ 117:225233. https://doi.org/10.1016/j.ecolecon.2014.07.017

Vatn A, Barton DN, Lindhjem H et al (2011) Can markets protect biodiversity? An evaluation of different financial mechanism, UMB Noragric Report 60. Aas 
Vermeulen WJV, Kok MTJ (2012) Government interventions in sustainable supply chain governance: experience in Dutch front-running cases. Ecol Econ 83:183-196. https://doi. org/10.1016/j.ecolecon.2012.04.006

Voß JP, Bornemann B (2011) The politics of reflexive governance: challenges for designing adaptive management and transition management. Ecol Soc 16:9

Voß J, Kemp R (2006) Sustainability and reflexive governance: introduction. In: Voß J-P, Bauknecht D, Kemp R (eds) Reflexive governance for sustainable development. Edward Elgar, Cheltenham, pp 3-28

Wilson GA (2008) From 'weak' to 'strong' multifunctionality: conceptualising farm-level multifunctional transitional pathways. J Rural Stud 24:367-383. https://doi.org/10.1016/j. jrurstud.2007.12.010

Zhang W, Ricketts TH, Kremen C et al (2007) Ecosystem services and dis-services to agriculture. Ecol Econ 64:253-260. https://doi.org/10.1016/j.ecolecon.2007.02.024

Zimmermann JB (2008) Le territoire dans l'analyse économique. Rev française Gest 184:105-118

Open Access This chapter is licensed under the terms of the Creative Commons Attribution 4.0 International License (http://creativecommons.org/licenses/by/4.0/), which permits use, sharing, adaptation, distribution and reproduction in any medium or format, as long as you give appropriate credit to the original author(s) and the source, provide a link to the Creative Commons licence and indicate if changes were made.

The images or other third party material in this chapter are included in the chapter's Creative Commons licence, unless indicated otherwise in a credit line to the material. If material is not included in the chapter's Creative Commons licence and your intended use is not permitted by statutory regulation or exceeds the permitted use, you will need to obtain permission directly from the copyright holder.

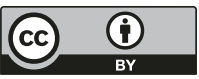

